could alone make those offers fruitful. There are two chief ways in which readers of HISTORY could help us : (i) By giving or lending to the Survey any volumes of records, either local or national, which could be placed at the disposal of the right people. Odd volumes especially are often of little value to their possessor but might be of the greatest value to the Survey. (ii) By notifying their county organiser that for the purposes of the Survey certain volumes of records in their possession were at the disposal of recognised helpers for use on loan.

Under the first heading we have already to record a most useful and generous gift from Mr. Farrer of his Yorkshire Charters and Feudal Cambridgeshire, of the Calendar of Charter Rolls, and of many sheets of the six-inch O.S. maps for Yorkshire.

The University,

Allen Mawer.

Liverpool.

\title{
The Paston Letters.
}

MaDAM,-Will you allow me to question Miss Thornley's statement (History, January 1922, p. 272), that a book of dried quinces meant 10 lbs. ? (1) The (Royal) Household Ordinances, quoted in New Oxford Dictionary under Charedequince, give the price in 1469: "Charequynses, $10 \mathrm{lb}$.- the book vs.- $£ 210 \mathrm{~s}$.," which can only mean that at 5s. the pound ten lbs. cost $f 210 s$. (2) The word is not wholly obsolete, but was, at any rate twenty years ago, in use in South Wales, meaning one $\mathrm{lb}$. (of dried quinces).

Copyright forbade copying from Gairdner's edition; but as my own study of the Paston Letters for a long period of years has naturally always been in Gairdner's editions, the defect is, or should be, more apparent than actual. I deliberately took Fenn's "modernised" version in preference to re-spelling myself : re-spelling is practically what modernising in this case amounts to. If Fenn is occasionally inadequate in annotation, his extraordinary accuracy and acumen were strongly insisted on by Gairdner himself. I tested a number of letters by Gairdner's latest version from the newly recovered MSS., and found a word inaccurate in one letter, in another, a list of prices omitted without the habitual note to that effect: $i$. e. two errata by Fenn's secretary, or copyist, only, out of some score of letters. As I have marked all notes taken from Fenn, few will observe what a large number of notes in Gairdner are Fenn's.

With regard to the credibility of personal and local comment on the exactions of Edward IV.- " "benevolences" not taxes-I cannot agree with the summary disregard of them which is now rather usual. All trade was then local and on a small scale, and coin always scarce. Does not the bitter feeling in Norfolk remind us of 1381, 1449, 1488, and 1497 ?

21 Dalebury Road, S.W. 17.

Alice D. Greenwood.

\section{The Postage Stamps of San Marino.}

MADAM,-May I point out one or two minor errors in Dr. William Miller's most interesting account of San Marino? (i) The Republic of Andorra has never issued postage stamps; a bogus issue, purporting to be made by the Andorran Government, appeared several 
years ago, but it had no official standing, and was made to deceive collectors only. As a matter of fact, postage within the Andorran boundaries is free; letters for abroad must have French or Spanish stamps affixed at the frontior. (ii) San Marino never surcharged Sardinian or Italian issues; possibly Dr. Miller means that such stamps were used in the Republio prior to 1877 , and were cancelled with the San Marino postmark, a rather different matter in philatelic eyes ! (iii) It is true that there was a separate issue in 1899 for internal use only, but this comprised only two values, $2 \mathrm{c}$. and $5 \mathrm{c}$., roughly $\frac{1}{4} d$. and $\frac{1}{2} d$., which would not in any case have been able to do much service on foreign letters! (iv) It is rather hard lines on San Marino to be classed with that parvenu principality (philatelically speaking) Liechtenstein, which in ten years has issued quite unnecessarily, and for stamp-collectors' benefit, more stamps by far than San Marino in nearly fifty. With the exception of one commemorative issue, all Sammarinese stamps have served a genuine postal need, and some are now of considerable rarity.

B. D. REeD.

(Hon. Superintendent, Beginners' Exchange Branch, Junior Philatelic Soc.).

Piddletrenthide Vicarage, Dorchester.

\section{ERRATA.}

(Vol. IV., No. 1, April 1922.)

P. 36, 1. 39. For Potolsk read Polotsk.

P. 45, 1. 4 from foot. For Strack read Streck.

Pp. 50-51. We much regret that in the review of the Liber Feodorum we omitted to state that the valuable introductions to which we referred, and also the whole scheme of the new edition and the execution of it, are due to Sir Henry Maxwell Lyte, the Deputy Keeper of the Public Records.

P. 74, l. 24. For Rayleigh read Raleigh. 